\title{
Electrochemical Biosensors for Determination of Organophosphorus Compounds: Review
}

\author{
Anjum Gahlaut ${ }^{1}$, Ashish Gothwal ${ }^{2}$, Anil K. Chhillar ${ }^{2}$, Vikas Hooda ${ }^{2 *}$ \\ ${ }^{1}$ Department of Biotechnology \& Molecular Medicine, Pt. B. D. Sharma University of Health Sciences, Rohtak, India \\ ${ }^{2}$ Centre for Biotechnology, Maharshi Dayanand University, Rohtak, India \\ Email: ${ }^{*}$ advance.biotech@gmail.com
}

Received April 2, 2012; revised May 3, 2012; accepted May 11, 2012

\begin{abstract}
In last few decades there is exponential increase in use of organophosphorus (OP) compounds as pesticides and insecticides leading to adverse effect on human population and live stock. There is a great need to develop portable analytical tools that are amenable for remediation and bioremediation process monitoring, where rapid analysis of large number of samples is essential. Determination of various organophosphorus compounds has been achieved by integrating biocomponents with different transducers. The close integration of the biological events with the generation of a signal offers the potential for fabricating compact and easy-to-use analytical tools of high sensitivity and specificity. With the availability of new materials, associated with new sensing techniques has led to remarkable innovations in the design and construction of organophosphorus biosensors. The present review describes the specifications of most of the electrochemical Organophosphorus biosensors reported till date.
\end{abstract}

Keywords: Organophosphorus Compounds; Acetylcholinestrase; Tyrosinase; Organophosphorus Hydrolase; Electrochemical; Biosensor

\section{Introduction}

Organophosphates (OPs) are usually esters, amides or thiol derivatives of phosphoric, phosphonic, or phosphinic acids, which have general structural formula (Figure 1) where R1 and R2 are alkyl-, alkoxy-, alkylthio-, or amido-groups. $\mathrm{X}$ is the acyl residue (labile fluorine-, cyano-, substituted or branched aliphatic, aromatic, or heterocyclic groups) [1,2].

Organophosphate (OP) compounds have found wide applications as pesticides and insecticides in agriculture and as chemical warfare agents in military practice. Worldwide, OP compounds account for over 38\% of the total pesticides used [3]. Commonly used organophosphates includes parathion, malathion, methyl parathion, chlorpyrifos, diazinon, dichlorvos, phosmet, fenitrothion, tetrachlorvinphos and azinphos methyl. Malathion is widely used in agriculture, residential landscaping, public recreation areas and in public health pest control pro-<smiles>[R][PH]([R])(=O)[O-]</smiles>

Figure 1. General structure of organophosphorus compounds.

${ }^{*}$ Corresponding author. grams such as mosquito eradication [4]. According to World Health Organization, every year there are three million pesticide poisonings, mostly OP-related, and 200,000 deaths worldwide that are attributed either as self-poisoning or occupational exposure [5]. Besides human exposure, there is also concern that these pesticides could leak into ground and municipal water supplies and pollute surrounding environment. Reports in the literature have expressed concern over exposure to non target organisms such as birds and fish, as well as the potential for human exposure from sources such as fresh fruits and vegetables and processed foods. These neurotoxic compounds, which are structurally similar to the nerve gases Soman and Sarin, irreversibly inhibit the enzyme acetylcholine esterase, essential for the functioning of the central nervous system in humans and insects, resulting in the build up of the neurotransmitter acetylcholine which interferes with muscular responses and in vital organs produce serious symptoms and eventually death [6-8]. Effective methods for degradation/ disposal of these toxic compounds are needed to ensure that human and environmental health will not be compromised by the continued use of OP-containing pesticides. Analytical tools to properly monitor the food quality, control any treatment of water may be adopted Laboratory-based methods which are commonly used for de- 
tection and measurement of OP pesticide residues include gas chromatography (GC), high-performance liquid chromatography (HPLC), and capillary electrophoresis $[9,10]$. The bioanalytical methods primarily include assays based on enzyme inhibition and immunoassay [11, 12]. Enzyme linked immunosorbant assays (ELISA) are quite sensitive to specific compounds such as ethylparathion or fenitrothion but, like most immunoassays require multiple incubations and generate contaminated plates, tubes, etc. In addition, the characteristics of cholinesterase-based assays and immunoassays for OP pesticides are not well suited to process control monitoring applications as these are typically expensive and time-consuming, further more requires trained man power. Also, laboratory-based methods are not amenable to remediation and bioremediation process monitoring where rapid analysis of large number of samples is essential. Organophosphorus hydrolase (OPH) catalyzes the hydrolysis of a wide range of OP pesticides [13]. The hydrolysis involves a pH change, as well as electroactive species generation. OPH-based assays respond to OP compounds as enzyme substrates rather than inhibitors or antigens this is not the case with acetylcholine esterase. Consequently, these assays can be reversible and require only the analyte of interest. However this method has disadvantages that it employs the free enzymes which can be used once only and the measurement is based on change in $\mathrm{pH}$ which limits its sensitivity. Biosensing approach was used to overcome problems of onsite monitoring sensitivity, reliability and ability to screen large number of samples.

\section{Electrochemical Biosensor}

The working of electrochemical biosensors is mainly based on the use of a biological component/bio-receptor element retained in direct contact with an electrochemically active transducer (electrode) to obtain an analytically useful signal by coupling biochemical and electrochemical interactions [14]. The principle of electrochemical sensors is that when an electro-active analyte is subjected to fixed or varying potential of some predefined patterns causes oxidation or reduction of analyte on the working electrode surface, which leads to the generation of an electrochemically measurable signal by the variation on electron fluxes. This signal can be measured by the electrochemical detector.

\subsection{Electrochemical OP Biosensor Based on Enzyme Inhibition Process}

Biosensors based on enzyme inhibition have found wide application for detection of toxic analyte (e.g., OP pesticides) which inhibit the functional activity of the enzyme. By determining the differences in enzyme activity with or without the presence of an inhibitor form the basis of analyte detection, according to the Equation (1):

$$
\mathrm{I} \%=\left[\left(\mathrm{A}_{0}-\mathrm{A}_{\mathrm{i}}\right) / \mathrm{A}_{0}\right] \times 100
$$

where $A_{0}$ is the activity without an inhibitor, and $A_{i}$ is with an inhibitor. The linear range is usually comprised between $20 \%$ and $80 \%$ of inhibition and the detection limit is usually defined as the amount of inhibitor which gives the decrease $20 \%$ of inhibition [15].

\subsubsection{Use of Acetylcholinesterase (AchE) Enzyme for Preparation of OP Biosensors}

The enzyme inhibition-based biosensors for the determination of OP pesticides is described by the following mechanism (2) [16].

Phosphorylated AchE enzymes has lower affinity for the substrate (Acetylcholine) called enzyme inhibition and the degree of inhibition is proportional to the concentration of OP compounds in the sample. Acetylcholinesterase (AchE) inhibition test, using AchE modified amperometric transducers is based on the measure of para-Aminophenol produced by hydrolysis of $p$-Aminophenyl acetate, or hydrogen peroxide generated as a result of the oxidation of choline produced from acetylcholine hydrolysis in the presence of choline oxidase. The inhibition of AchE enzyme due to the presence of OP compounds results in reduced reagent consumption and products release is correspondingly detected applying electrochemical techniques and is correlated to the OP pesticides concentration.

AchE enzyme was used in combination with different types of supports for the fabrication of bio-sensing devices [17-34]. Table 1 summarizes the characteristics of different AchE-based biosensors. Although, sensitive biosensors based on AchE inhibition have few limitations: 1) since ChE is inhibited by neurotoxins which include not only OP pesticides but also carbamate pesticides and many other compounds, these analytical tools, are not selective and cannot be used for quantitation of either an individual or a class of pesticides which may be required to monitor detoxification processes, for example, detoxi-

$$
\begin{array}{cc}
\mathrm{O} & \mathrm{O} \\
\| & \| \\
\mathrm{EH}+(\mathrm{OR})_{2} \mathrm{P}-\mathrm{X} \rightarrow & (\mathrm{RO})_{2} \mathrm{P}-\mathrm{E} \quad+\mathrm{HX} \\
(\text { Enzyme }) \text { (OP pesticide) } & \text { (Phosphorylated enzyme) }
\end{array}
$$


Table 1. Characteristics of electrochemical Acetylcholinesterase-based biosensors for OP pesticides detection.

\begin{tabular}{|c|c|c|c|c|c|c|c|}
\hline Sr. No. & Target analyte & Detection technique & $\begin{array}{l}\text { Enzyme immobilization } \\
\text { technique }\end{array}$ & Electrode/transducer & Linearity range (M) & $\begin{array}{l}\text { Detection } \\
\text { limit }\end{array}$ & Ref. \\
\hline 1. & Paraoxon & Amperometry & Adsorption & $\begin{array}{l}\text { AuNPs, grapheme oxide } \\
\text { nanosheets }\end{array}$ & ND & $10^{-13}$ & [34] \\
\hline 2. & Chlorpyrifos oxon & Amperometry & Entrapment & $\begin{array}{l}\text { 7,7,8,8-tetracyano } \\
\text { quinodimethane }\end{array}$ & $6 \times 10^{-9}-2.4 \times 10^{-9}$ & $6 \times 10^{-9}$ & [39] \\
\hline 3. & Chloropyrifos & Amperometry & Covalence & ZnS NPs Au & $1.5 \times 10^{-9}-4 \times 10^{-8}$ & ND & [37] \\
\hline 4. & Paraoxon & Amperometry & Affinity & MWCNT & $3.6 \times 10^{-14}-3.6 \times 10^{-11}$ & $5 \times 10^{-15}$ & [40] \\
\hline 5. & Chlorpyrifos oxon & $\mathrm{CV}$ & Entrapment & PEDOT:PSS & ND & $4 \times 10^{-9}$ & [38] \\
\hline 6. & Chloropyrifos & SWV & Cross-linking & SWCNT & $10^{-11}-10^{-6}$ & $10^{-12}$ & [36] \\
\hline 7. & Chloropyrifos & $\mathrm{CV}$ & Covalent binding & $\begin{array}{l}\text { Exfoliated graphite } \\
\text { nanoplatelets }\end{array}$ & ND & $1.58 \times 10^{-10}$ & ${ }^{10}[35]$ \\
\hline 8. & Paraoxon & Amperometry & Entrapment & - & $1.3 \times 10^{-7}-5 \times 10^{-6}$ & $3.5 \times 10^{-2}$ & 2 [41] \\
\hline 9. & Paraoxon & Amperometry & Cross-linking & CoPc-Prussian Blue & $7.3 \times 10^{-9}-1.8 \times 10^{-8}$ & $7.3 \times 10^{-9}$ & 9 [42] \\
\hline 10. & Methyl paraoxon & Amperometry & Entrapment & $\mathrm{CoPc}$ & $2 \times 10^{-9}-4 \times 10^{-6}$ & $2.6 \times 10^{-9}$ & ${ }^{9}[43]$ \\
\hline 11. & Triazophos & Amperometry & Adsorption & MWCNT & $3 \times 10^{-8}-7.8 \times 10^{-6}$ & $10^{-8}$ & [44] \\
\hline 12. & Dichlorvos & Amperometry & Adsorption & - & ND & $10^{-10}$ & [45] \\
\hline 13. & Dichlorvos & Amperometry & Entrapment & $\mathrm{CoPc}$ & ND & $7 \times 10^{-12}$ & [46] \\
\hline 14. & Dichlorvos & Amperometry & Adsorption & - & Up to $10^{-16}$ & $10^{-17}$ & [47] \\
\hline 15. & Dichlorvos & Amperometry & Cross-linking & Prussian blue & $4.52 \times 10^{-11}-4.52 \times 10^{-8}$ & $1.13 \times 10^{-11}$ & ${ }^{-11}[48]$ \\
\hline 16. & Trichlorfon & Amperometry & Adsorption & $\mathrm{TiO}_{2}$ and $\mathrm{PbO}_{2}$ particles & $10^{-8}-2 \times 10^{-5}$ & $10^{-10}$ & [49] \\
\hline 17. & Monocrotophos & Amperometry & Adsorption & AuNPs & $4.5 \times 10^{-9}-4.5 \times 10^{-6}$ & $2.7 \times 10^{-9}$ & ${ }^{9}[50]$ \\
\hline 18. & Monocrotophos & Amperometry & Covalent binding & AuNPs-QDs & $4.5 \times 10^{-9}-4.5 \times 10^{-6}$ & $1.3 \times 10^{-9}$ & [51] \\
\hline 19. & Acephate & FET & Affinity & CNTs & ND & $5.45 \times 10^{-14}$ & ${ }^{14}[52]$ \\
\hline 20. & Dimethoate & Amperometry & Adsorption & $\begin{array}{l}\text { CNTs, zirconia NPs, } \mathrm{Au} \\
\text { colloid coated } \mathrm{Fe}_{3} \mathrm{O}_{4} \\
\text { magnetic NPs, Prussian } \\
\text { blue }\end{array}$ & $4.4 \times 10^{-6}-4.4 \times 10^{-2}$ & $2.4 \times 10^{-6}$ & ${ }^{6}$ [29] \\
\hline 21. & Chlorphenvinphos & Amperometry & - & CNTs & $4.90 \times 10^{-7}-7.46 \times 10^{-6}$ & $1.15 \times 10^{-7}$ & ${ }^{-7}[30]$ \\
\hline 22. & Malathion & Amperometry & Covalent binding & $\mathrm{Fe}_{3} \mathrm{O}_{4} \mathrm{NP}, \mathrm{c}-\mathrm{MWCNT}, \mathrm{Au}$ & $10^{-10}-4 \times 10^{-8}$ & $10^{-10}$ & [32] \\
\hline 23. & Chlorpyrifosoxon & $\mathrm{CV}$ and amperometry & Entrapment & PEDOT & & $1 \times 10^{-10}$ & [33] \\
\hline
\end{tabular}

fication of OP pesticides. 2) These protocols involve multiple steps requiring measurement of the uninhibited activity of ChE, followed by incubation of the sensor with the analyte sample for 10 - 15 min (and even longer for good sensitivity) and the measurement of the ChE again to determine the degree of inhibition. A final step of reactivation/regeneration, which in many cases is partial and in some cases not possible due to irreversible inhibition, is necessary if the electrode has to be reused.

\subsubsection{Tyrosine Based OP Biosensor}

Tyrosinase through its cresolate activity catalyses the ohydroxylation of monophenol to o-diphenol, which is further to o-quinone by its catecholase activity. Tyrosi- nase activity is inhibited by carbamates pesticides and atrizine that lowers the sensitivity of tyrosinase-based biosensors. The Tyrosinase enzyme is inherently unstable and is responsible for reducing the lifetime of the tyrosinase-based biosensors. However, tyrosinase has high optimum temperatures and there is no effect of organic solvents on the activity of enzyme tyrosinase. Numerous electrochemical biosensors based on the inhibition of tyrosinase activity have been reported (Table 2).

\subsection{OPH Biosensor Based on Direct Catalytic Enzymatic Reaction}

In 1970s, Flavobacterium sp. ATCC 27551 and B. di- 
minuta were the first OP-degrading bacteria isolated from soil samples $[57,58]$. Organophosphorus hydrolase (OPH) has broad substrate specificity and is able to hydrolyze a number of OP pesticides such as paraoxon, parathion, coumaphos, diazinon, dursban, methyl parathion [13]. The hydrolysis involves a $\mathrm{pH}$ change, as well as electroactive species generation, thus allowing the development of potentiometric and amperometric sensors for OP pesticides quantification [59-65]. The change in $\mathrm{pH}$ was measured using a $\mathrm{pH}$ electrode and there were drawbacks of sensitivity, calibration. OPH catalyzed hydrolysis of parathion, methyl parathion, paraoxon, fenitrothion, etc. yields 4-nitrophenol. The current of 4-nitrophenol oxidation is proportional to the OP pesticide concentration, is recorded as a biosensor response. OP biosensors have been successfully created using organophosphorous hydrolase as the active component [66]. PTE-immobilized biosensors allow for the direct detection of Ops. However, these biosensors show lower sensitivity values and higher detection limits than cholinesterase-based biosensors. Moreover, they can only detect some Organophosphorus (OP) compounds. The Drawback with such type of sensors is that the potential applied for oxidation of 4-nitrophenol lead to denaturation of the enzyme immobilized on working electrode and thus leads to decrease in activity and reusability. Secondly the potential may oxidize other electro active species that may lead to generation of additional current and false positive results. Characteristics of the other relevant
$\mathrm{OPH}$ based electrochemical biosensors based are sumarised in Table 3.

\section{Recent Developments in the Fabrication of Electrochemical Biosensors for OP Pesticides Determination}

Nanomaterials transducer modification and genetic engineering of the biocomponents are the main strategies to overcome the reported drawbacks of low sensitivity and reusability/regeneration of working electrode. The electro-catalytical properties of the nanostructures includes their action as electron transfer mediators or electrical wires, large surface to volume ratio, structural robustness, and biocompatibility enhances the use of nano-technological approach in electrochemical biosensors development [74]. Therefore, it gives several advantages like electrode potential lowering, enhancement of the electron transfer rate with no electrode surface fouling, sensitivity increase, stability improvement, and interface functionalization, for developing a bio-sensing system. Various nanomaterials are used for making insoluble support for acetylcholinesterase immobilization in electrochemical biosensors for organophosphorus pesticides determination [75]. By the help of transducer modification with nanomaterials, it gives opportunity to develop biosensors with long storage stability and enables OP pesticides detection in the nanomole-picomole range. The another route leading to increase the biosensors sensitivity, selec-

Table 2. Characteristics of electrochemical inhibition-based biosensors using tyrosinase for OP pesticides detection.

\begin{tabular}{|c|c|c|c|c|c|c|}
\hline Sr. no. & Target analyte & $\begin{array}{l}\text { Detection } \\
\text { method }\end{array}$ & $\begin{array}{l}\text { Enzyme immobilization } \\
\text { technique }\end{array}$ & Electrode materials & Linearity range (M) & $\begin{array}{l}\text { Detection } \\
\text { limit (M) }\end{array}$ \\
\hline 1. & Dichlorvos & Amperometry & Cross-linking + entrapment & 1,2-naphthoquinone-4-sulfonate (NQS) & Up to $8 \times 10^{-6}$ & $6 \times 10^{-8}[53]$ \\
\hline 3. & Methyl parathion & Amperometry & Cross-linking & CoPc & $2.28 \times 10^{-8}-3.8 \times 10^{-7}$ & ND [54] \\
\hline 3. & Diazinon & Amperometry & Cross-linking & $\mathrm{CoPc}$ & $6.24 \times 10^{-8}-1.64 \times 10^{-7}$ & ND \\
\hline 4. & Dimethoate & Amperometry & Adsorption & - & $2 \times 10^{-6}-2 \times 10^{-1}$ & $10^{-6} \quad[55]$ \\
\hline 5. & Paraoxon & Amperometry & Adsorption & - & $10^{-5}-10^{-2}$ & $5 \times 10^{-6}[55]$ \\
\hline 6. & Malathion & Amperometry & Adsorption & - & $10^{-5}-10^{-2}$ & $5 \times 10^{-6}[55]$ \\
\hline 7. & Paraoxon & Amperometry & Cross-linking & Prussian blue & $10^{-7}-10^{-6}$ & $10^{-7} \quad[56]$ \\
\hline
\end{tabular}

Table 3. Characteristics of different OPH-based electrochemical biosensors OP pesticides detection.

\begin{tabular}{cccccrrr}
\hline Sr. no. & Target analyte & Detection technique & Immobilization method & Transducer & Linearity range (M) & Detection limit (M) Ref. \\
\hline 1. & Paraoxon & Amperometry & Covalent binding & SWCNTs & $5 \times 10^{-7}-8.5 \times 10^{-6}$ & $10^{-8}$ & {$[67]$} \\
2. & Paraoxon & Amperometry & Entrapment & Mesoporous Carbon & $2 \times 10^{-7}-8 \times 10^{-6}$ & $1.2 \times 10^{-7}$ & {$[68]$} \\
3. & Paraoxon & Amperometry & Entrapment & MWCNTs & Up to $4 \times 10^{-6}$ & $15 \times 10^{-8}$ & {$[69]$} \\
4. & Paraoxon & Amperometry & Cross-linking & MWCNTs & $5 \times 10^{-7}-2 \times 10^{-6}$ & $0.314 \times 10^{-6}$ & {$[70]$} \\
5. & Ethyl Parathion & Amperometry & Covalent binding & - & ND & $<3.4 \times 10^{-9}$ & {$[71]$} \\
6. & Methyl Parathion & Amperometry & Covalent binding & AuNPs-MWCNTs-QDs & $1.9 \times 10^{-8}-7.6 \times 10^{-7}$ & $3.8 \times 10^{-9}$ & {$[72]$} \\
7. & Parathion & Amperometry & Cross-linking & CNTs & $2 \times 10^{-9}-4 \times 10^{-8}$ & $15 \times 10^{-9}$ & {$[73]$} \\
\hline
\end{tabular}


tivity and stability involves the incorporation of tailor designed biorecognition elements in the biosensing platform. Increased bio-recognition element affinity for the target analyte favoring the accessibility of the active site, enhanced electron transfer, and oriented or more stable immobilization can be achieved by appropriate site-directed mutagenesis [76]. Genetically modified enzymes such as AchE, are extensively used in inhibition based biosensors for OP pesticides determination [33], allowing attaining LOD as low as $10^{-17} \mathrm{M}$ [47].

\section{Conclusion}

Electrochemical biosensors have been found to be suitable for the monitoring of OP compounds. Signal magnification and miniaturization have been achieved by the innovation in fabrication techniques with the use of new materials. With the discovery of new mediators, it is possible to build up an electronic interface between a redox enzyme and transducer for improved signal transmission. From decades variety of prototype have been successfully develop to monitor the conc. of OP compounds. There is a great need for commercial exploitation of the technology for development of portable devices that can be used for field monitoring by untrained manpower.

\section{Acknowledgements}

Financial support to Centre for Biotechnology from DST (FIST) and UGC (SAP) is greatly acknowledged.

\section{REFERENCES}

[1] J. Jeyaratnam and M. Maroni, "Organophosphorous Compounds,” Toxicology, Vol. 91, No. 1, 1994, pp. 15-27. doi:10.1016/0300-483X(94)90236-4

[2] F. Worek, M. Koller, H. Thiermann and L. Szinicz, "Diagnostic Aspects of Organophosphate Poisoning," Toxicology, Vol. 214, No. 3, 2005, pp. 182-189. doi:10.1016/j.tox.2005.06.012

[3] B. K. Singh, "Organophosphorus-degrading Bacteria: Ecology and Industrial Applications,” Nature Reviews Microbiology, Vol. 7, 2009, pp. 156-164.

[4] Environmental Protection Agency, "Malathion for Mosquito Control,” 2008.

http://epa.gov/opp00001/health/mosquitoes/malathion4m osquitoes.html

[5] S. B. Bird, T. D. Sutherland, C. Gresham, J. Oakeshott, C. Scott and M. Eddleston, "OpdA, a Bacterial Organophosphorus Hydrolase, Prevents Lethality in Rats after Poisoning with Highly Toxic Organophosphorus Pesticides," Toxicology, Vol. 247, No. 2-3, 2008, pp. 88-92. doi:10.1016/j.tox.2008.02.005

[6] W. J. Donarski, D. P. Dumas, D. P. Heitmeyer, V. E. Lewis and F. M. Raushel, "Structure-Activity Relationships in the Hydrolysis of Substrates by the Phosphotriesterase from Pseudomonas diminuta," Biochemistry, Vol.
28, No. 11,1989 , pp. $4650-4655$ doi:10.1021/bi00437a021

[7] S. Chapalamadugu and G. S. Chaudhry, "Microbiological and Biotechnological Aspects of Metabolism Carbamates and Organophosphates," Critical Reviews in Biotechnology, Vol. 12, 1992, pp. 357-389. doi:10.3109/07388559209114232

[8] J. A. Compton, "Military Chemical and Biological Agents," Telford Press, New Jersey, 1988.

[9] J. Sherma, "Pesticides," Analytical Chemistry, Vol. 65, No. 12, 1993, pp. 40-54. doi:10.1021/ac00060a004

[10] S. Yao, A. Meyer and G. Henze, "Comparison of Amperometric and UV-Spectrophotometric Monitoring in HPLC Analysis of Pesticides," Fresenius Journal of Analytical Chemistry, Vol. 339, No. 4, 1991, pp. 207-211. doi:10.1007/BF00325738

[11] P. Skladal, "Biosensors Based on Cholinesterase for Detection of Pesticides," Food Technology and Biotechnology, Vol. 34, 1996, pp. 43-49.

[12] E. P. Meulenberg, W. H. Mulder and P. G. Stoks, "Immunoassays for Pesticides," Environmental Science and Technology, Vol. 29, No. 3, 1995, pp. 553-561. doi:10.1021/es00003a001

[13] D. M. Munnecke, "Enzymatic Detoxification of Waste Organophosphate Pesticides," Journal of Agricultural and Food Chemistry, Vol. 28, No. 1, 1980, pp. 105-111. doi:10.1021/jf60227a025

[14] D. R. Thévenot, K. Tóth, R. A. Durst and G. S. Wilson, "Electrochemical Biosensors: Recommended Definitions and Classification," Pure and Applied Chemistry, Vol. 71, No. 12, 1999, pp. 2333-2348. doi:10.1351/pac199971122333

[15] A. Amine, H. Mohammadi, I. Bourais and G. Palleschi, "Enzyme Inhibition-Based Biosensor for Food Safety and Environmental Monitoring," Biosensors and Bioelectronics, Vol. 21, No. 8, 2006, pp. 1405-1423. doi:10.1016/j.bios.2005.07.012

[16] W. N. Aldridge, "Some Properties of Specific Cholinesterase with Particular Reference to the Mechanism of Inhibition by Diethyl p-Nitrophenyl Thiophosphate (E605) and Analogies," Biochemical Journal, Vol. 46, No. 4, 1950, pp. 451-460.

[17] M. Harlbert and R. Baldwin, "Electrocatalytic and Analytical Response of Cobalt-Phthalocyanine Containing Carbon Paste Electrodes towards Sulfhydryl Compounds," Analytical Chemistry, Vol. 57, No. 3, 1985, pp. 591-595. doi:10.1021/ac00280a007

[18] E. N. Navera, K. Sode, E. Tamiya and I. Karube, "Development of Acetylcholine Sensor Using Carbon Fiber (Amperometric Determination)," Biosensors and Bioelectronics, Vol. 6, No. 8, 1991, pp. 675-680. doi:10.1016/0956-5663(91)87021-3

[19] P. Skladal, "Determination of Organophosphate and Carbamate Pesticides Using a Cobalt Phthalocyanine-Modified Carbon Paste Electrode and a Cholinesterase Enzyme Membrane," Analytica Chimica Acta, Vol. 252, 1991, pp. 1-2. doi:10.1016/0003-2670(91)87190-I

[20] P. Skladal and M. Mascini, "'Sensitive Detection of Pes- 
ticides Using Amperometric Sensors Based on Cobalt Phthalocyanine-Modified Composite Electrodes and Immobilized Cholinesterases,' Biosensors and Bioelectronics, Vol. 7, No. 5, 1992, pp. 335-343. doi:10.1016/0956-5663(92)85029-A

[21] D. Martorell, F. Céspedes, E. Martínez-Fàbregas and S. Alegret, "Amperometric Determination of Pesticides Using a Biosensor Based on a Polishable Graphite-Epoxy Biocomposite," Analytica Chimica Acta, Vol. 290, No. 3, 1994, pp. 343-348. doi:10.1016/0003-2670(94)80121-5

[22] G. Evtugyn, H. Budnikov, G. Yu and E. Suntsov, “Amperometric Determination of Thiocholine Esters in the Presence of Butyrylcholinesterase," Zhurnal Analiticheskoi Khimii, Vol. 51, No. 4, 1996, pp. 391-393.

[23] D. Martorell, F. Céspedes, E. Martínez-Fàbregas and S. Alegret, "Determination of Organophosphorus and Carbamate Pesticides Using a Biosensor Based on a Polishable, 7,7,8,8-Tetracyanoquino-Dimethane-Modified, Graphite-Epoxy Biocomposite,” Analytica Chimica Acta, Vol. 337, No. 3, 1997, pp. 305-313. doi:10.1016/S0003-2670(96)00384-4

[24] S. Hernandez, I. Palchetti and M. Mascini, "Determination of Anticholinesterase Activity for Pesticides Monitoring Using a Thiocholine Sensor," International Journal of Environmental Analytical Chemistry, Vol. 78, No. 3-4, 2000, pp. 263-278. doi:10.1080/03067310008041346

[25] F. Ricci, F. Arduini, A. Amine, D. Moscone and G. Palleschi, "Characterisation of Prussian Blue Modified Screen-Printed Electrodes for Thiol Detection," Journal of Electroanalytical Chemistry, Vol. 563, No. 2, 2004, pp. 229-237. doi:10.1016/j.jelechem.2003.09.016

[26] K. A. Joshi, J. Tang, R. Haddon, J. Wang, W. Chen and A. Mulchandani, “A Disposable Biosensor for Organophosphorus Nerve Agents Based on Carbon Nanotubes Modified Thick Film Strip Electrode,” Electroanalysis, Vol. 17, No. 1, 2005, pp. 54-58. doi:10.1002/elan.200403118

[27] M. Pohanka, P. Dobes, L. Dritinova and K. Kuca, "Nerve Agents Assay Using Cholinesterase Based Biosensor," Electroanalysis, Vol. 21, No. 10, 2009, pp. 1177-1182. doi:10.1002/elan.200804528

[28] F. Arduini, A. Cassisi, A. Amine, F. Ricci, D. Moscone and G. Palleschi, "Electrocatalytic Oxidation of Thiocholine at Chemically Modified Cobalt Exacyanoferrate Screen-Printed Electrodes,” Journal of Electroanalytical Chemisrty, Vol. 626, No. 1-2, 2009, pp. 66-74. doi:10.1016/j.jelechem.2008.11.003

[29] N. Gan, X. Yang, D. Xie, Y. Wu and W. Wen, “A Disposable Organophosphorus Pesticides Enzyme Biosensor Based on Magnetic Nano-Particles Modified Screen Printed Carbon Electrode,” Sensors, Vol. 10, No. 1, 2010, pp. 665-638. doi:10.3390/s100100625

[30] A. C. Oliveira and L. H. Mascaro, "Evaluation of Acetylcholinesterase Biosensor Based on Carbon Nanotube Paste in the Determination of Chlorphenvinphos," International Journal of Analytical Chemistry, Vol. 2011, 2011, pp. 1-6. doi:10.1155/2011/974216

[31] D. Du, J. Wang, L. Wang, D. Lu, J. N. Smith, C. Tim- chalk and Y. Lin, "Magnetic Electrochemical Sensing Platform for Biomonitoring of Exposure to Organophosphorus Pesticides and Nerve Agents Based on Simultaneous Measurement of Total Enzyme Amount and Enzyme Activity,” Analytical Chemistry, Vol. 83, No. 10, 2011, pp. 3770-3777. doi:10.1021/ac200217d

[32] N. Chauhan and C. S. Pundir, "An Amperometric Biosensor Based on Acetylcholinesterase Immobilized onto Iron Oxide Nanoparticles/Multi-Walled Carbon Nanotubes Modified Gold Electrode for Measurement of Organophosphorus Insecticides,” Analytica Chimica Acta, Vol. 701, No. 1, 2011, pp. 66-74. doi:10.1016/j.aca.2011.06.014

[33] T. Sikora, G. Istamboulie, E. Jubete, E. Ochoteco, J. L. Marty and T. Noguer, "Highly Sensitive Detection of Organophosphate Insecticides Using Biosensors Based on Genetically Engineered Acetylcholinesterase and Poly (3,4-Ethylenedioxythiophene)," Journal of Sensors, Vol. 2011, 2011, pp. 1-7. doi:10.1155/2011/102827

[34] Y. Wang, S. Zhang, D. Du, Y. Shao, Z. Li, J. Wang, M. H. Engelhard, J. Li and Y. Lin, "Self Assembly of Acetylcholinesterase on a Gold Nanoparticles-Grapheme Nanosheet Hybrid for Organophosphate Pesticide Detection Using Polyelectrolyte as a Linker,” Journal of Materials Chemistry, Vol. 21, No. 14, 2011, pp. 5319-5325. doi:10.1039/c0jm03441j

[35] A. C. Ion, I. Ion, A. Culetu, D. Gherase, C. A. Moldovan, R. Iosub and A. Dinescu, "Acetylcholinesterase Voltammetric Biosensors Based on Carbon Nanostructure-Chitosan Composite Material for Organophosphate Pesticides,” Materials Science and Engineering, Vol. 30, No. 6, 2010, pp. 817-821. doi:10.1016/j.msec.2010.03.017

[36] S. Viswanathan, H. Radecka and J. Radecki, "Electrochemical Biosensor for Pesticides Based on Acetylcholinesterase Immobilized on Polyaniline Deposited on Vertically Assembled Carbon Nanotubes Wrapped with ssDNA," Biosensors and Bioelectronics, Vol. 24, No. 9, 2009, pp. 2772-2777. doi:10.1016/j.bios.2009.01.044

[37] N. Chauhan, J. Narang and C. S. Pundir, "Immobilization of Rat Brain Acetylcholinesterase on ZnS and Poly (Indole-5-carboxylic acid) Modified Au Electrode for Detection of Organophosphorus Insecticides," Biosensors and Bioelectronics, Vol. 29, No. 1, 2011, pp. 82-88. doi:10.1016/j.bios.2011.07.070

[38] G. Istamboulie, T. Sikora, E. Jubete, E. Ochoteco, J. L. Marty and T. Noguer, "Screen-Printed Poly(3,4-Ethylenedioxythiophene) (PEDOT): A New Electrochemical Mediator for Acetylcholinesterase-Based Biosensors,” Talanta, Vol. 82, No. 3, 2010, pp. 957-961. doi:10.1016/j.talanta.2010.05.070

[39] A. Hildebrandt, R. Bragos, S. Lacorte and J. L. Marty, "Performance of a Portable Biosensor for the Analysis of Organophosphorus and Carbamate Insecticides in Water and Food," Sensors and Actuators B, Vol. 133, No. 1, 2010, pp. 195-201. doi:10.1016/j.snb.2008.02.017

[40] Y. Ivanov, I. Marinov, K. Gabrovska, N. Dimcheva and T. Godjevargova, "Amperometric Biosensor Based on a Site-Specific Immobilization of Acetylcholinesterase via 
Affinity Bonds on a Nanostructured Polymer Membrane With Intergrated Multiwall Carbon Nanotubes," Journal of Molecular Catalysis B: Enzymatic, Vol. 63, No. 3-4, 2010, pp. 141-148. doi:10.1016/j.molcatb.2010.01.005

[41] R. Sinha, M. Ganesana, S. Andreescu and L. Stanciu, "AchE Biosensor Based on Zinc Oxide Sol-Gel for the Detection of Pesticides," Analytica Chimica Acta, Vol. 661, No. 2, 2010, pp. 195-199. doi:10.1016/j.aca.2009.12.020

[42] F. Arduini, F. Ricci, C. S. Tuta, D. Moscone, A. Amine and G. Palleschi, "Detection of Carbamic and Organophosphorous Pesticides in Water samples Using a Cholinesterase Biosensor Based on Prussian Blue-Modified Screen-Printed Electrode," Analytica Chimica Acta, Vol. 580, No. 2, 2006, pp. 155-162. doi:10.1016/j.aca.2006.07.052

[43] G. Valdes-Ramirez, M. Cortina, M. T. Ramirez-Silva and J. L. Marty, “Acetylcholinesterase-Based Biosensors for Quantification of Carbofuran, Methylparaoxon, and Dichlorvos in 5\% Acetonitrile," Analytical and Bioanalytical Chemistry, Vol. 392, No. 4, 2008, pp. 699-707. doi:10.1007/s00216-008-2290-7

[44] D. Du, X. Huang, J. Cai and A. Zhang, “Amperometric Detection of Triazophos Pesticide Using Acetylcholinesterase Biosensor Based on Multiwall Carbon Nanotube-Chitosan Matrix," Sensors and Actuators B, Vol. 127, No. 2, 2007, pp. 531-535. doi:10.1016/j.snb.2007.05.006

[45] A. Vakurov, C. E. Simpson, C. L. Daly, T. D. Gibson and P. A. Millner, "Acetylcholinesterase-Based Biosensor Electrodes for Organophosphate Pesticide Detection. I. Modification of Carbon Surface for Immobilization of Acetylcholinesterase," Biosensors and Bioelectronics, Vol. 20, No. 6, 2004, pp. 1118-1125. doi:10.1016/j.bios.2004.03.039

[46] G. Valdes-Ramirez, D. Fournier, M. T. Ramirez-Silva and J. L. Marty, "Sensitive Amperometric Biosensor for Dichlorovos Quantification: Application to Detection of Residues on Apple Skin,” Talanta, Vol. 74, No. 4, 2008, pp. 741-746. doi:10.1016/j.talanta.2007.07.004

[47] S. Sotiropoulou, D. Fournier and N. A. Chaniotakis, "Genetically Engineered Acetylcholinestrase-Based-Biosensor for Attomolar Detection of Dichlorvos," Biosensors and Bioelectronics, Vol. 20, No. 11, 2005, pp. 2347-2352. doi:10.1016/j.bios.2004.08.026

[48] X. Sun and X. Wang, “Acetylcholinesterase Biosensor Based on Prussian Blue-Modified Electrode for Detecting Organophosphorous Pesticides," Biosensors and Bioelectronics, Vol. 25, No. 1-2, 2010, pp. 2611-2614. doi:10.1016/j.bios.2010.04.028

[49] Y. Wei, Y. Li, Y. Qu, F. Xiao, G. Shi and L. Jin, “A Novel Biosensor Based on Photoelectro-Synergistic Catalysis for Flow-Injection Analysis System/Amperometric Detection of Organophosphorous Pesticides," Analytica Chimica Acta, Vol. 643, No. 1-2, 2009, pp. 13-18. doi:10.1016/j.aca.2009.03.045

[50] D. Du, S. Chen, J. Cai and A. Zhang, "Immobilization of Acetylcholinesterase on Gold Nanoparticles Embedded in Sol-Gel Film for Amperometric Detection of Organo- phosphorous," Biosensors and Bioelectronics, Vol. 23, No. 1, 2007, pp. 130-134.

doi:10.1016/j.bios.2007.03.008

[51] D. Du, S. Chen, D. Song, H. Li and X. Chen, "Development of Acetylcholinesterase Biosensor Based on CdTe Quantum Dots/Gold Nanoparticles Modified Chitosan Microspheres Interface," Biosensors and Bioelectronics, Vol. 24, No. 3, 2008, pp. 475-479. doi:10.1016/j.bios.2008.05.005

[52] A. Ishii, S. Takeda, S. Hattori, K. Sueoka and K. Mukasa, "Ultrasensitive Detection of Organophosphate Insecticides by Carbon Field-Effect Transistor," Colloids and Surfaces A, Vol. 313-314, 2008, pp. 456-460. doi:10.1016/j.colsurfa.2007.05.071

[53] J. C. Vidal, S. Esteban, J. Gil and J. R. Castillo, “A Comparative Study of Immobilization Methods of a Tyrosinase Enzyme on Electrodes and their Application to the Detection of Dichlorvos Organophosphorus Insecticide,” Talanta, Vol. 68, No. 3, 2006, pp. 791-799. doi:10.1016/j.talanta.2005.06.038

[54] Y. D. de Albuquerque and L. F. Ferreira, “Amperometric Biosensing of Carbamate and Organophosphate Pesticides Utilizing Screen-Printed Tyrosinase-Modified Electrodes," Analytica Chimica Acta, Vol. 596, No. 2, 2007, pp. 210-221. doi:10.1016/j.aca.2007.06.013

[55] L. Campanella, D. Lelo, E. Martini and M. Tomassetti, "Organophosphorus and Carbamate Pesticide Analysis Using an Inhibition Tyrosinase Organic Phase Enzyme Sensor; Comparison by Butyrylcholinesterase + Choline Oxidase Opee and Application to Natural Waters," Analytica Chimica Acta, Vol. 587, No. 1, 2007, pp. 22-32. doi:10.1016/j.aca.2007.01.023

[56] S. Sajjadi, H. Ghourchian and H. Tavakoli, "Choline Oxidase as a Selective Recognition Element for Determination of Paraoxon," Biosensors and Bioelectronics, Vol. 24, No. 8, 2009, pp. 2509-2514. doi:10.1016/j.bios.2009.01.008

[57] N. Sethunathan and T. Yoshida, "A Flavobacterium sp. That Degrades Diazinon and Parathion," Canadian Journal of Microbiology, Vol. 19, 1973, pp. 873-875. doi:10.1139/m73-138

[58] D. M. Munnecke and D. P. Hsieh, "Pathways of Microbial Metabolism of Parathion," Applied and Environmental Microbiology, Vol. 31, 1976, pp. 63-69.

[59] J. Anzai, "Use of Biosensors for Detecting Organophosphorus Agents,” Yakugaku Zasshi, Vol. 126, No. 12, 2006, pp. 1301-1308. doi:10.1248/yakushi.126.1301

[60] C. Lei, M. Valenta, K. P. Sapiralli and E. J. Ackerman, "Biosensing Paraoxon in Simulated Environmental Samples by Immobilized Organophosphorus Hydrolase in Functionalized Mesoporous Silica,” Journal of Environmental Quality, Vol. 36, No. 1, 2007, pp. 233-238. doi:10.2134/jeq2006.0216

[61] A. Mulchandani, W. Chen, P. Mulchandani, J. Wang and K. R. Rogers, "Biosensors for Direct Determination of Organophosphate Pesticides,” Biosensors and Bioelectronics, Vol. 16, No. 4-5, 2001, pp. 225-230. doi:10.1016/S0956-5663(01)00126-9

[62] P. Mulchandani, W. Chen and A. Mulchandani, "Flow 
Injection Amperometric Enzyme Biosensor for Direct Determination of Organophosphate Nerve Agents," Environmental Science and Technology, Vol. 35, No. 12, 2001, pp. 2562-2565. doi:10.1021/es001773q

[63] B. Prieto-Simon, M. Campàs, S. Andreescu and J. L. Marty, "Trends in Flow-Based Biosensing Systems for Pesticide Assessment,” Sensors, Vol. 6, No. 10, 2006, pp. 1161-1186. doi:10.3390/s6101161

[64] S. Rodriguez-Mozaz, M. P. Marco, M. J. Lopez de Alda and D. P. Barcelo, "Biosensors for Environmental Applications: Future Development Trends,” Pure and Applied Chemistry, Vol. 76, No. 4, 2004, pp. 723-752. doi:10.1351/pac200476040723

[65] J. Wang, R. Krause, K. Block, M. Musameh, A. Mulchandani and M. J. Schoning, "Flow Injection Amperometric Detection of OP Nerve Agents Based on an Organophosphorus-Hydrolase Biosensor Detector," Biosensors and Bioelectronics, Vol. 18, No. 2-3, 2003, pp. 255260. doi:10.1016/S0956-5663(02)00178-1

[66] Y. Lei, P. Mulchandani, J. Wang, W. Chen and A. Mulchandani, "Highly Sensitive and Selective Amperometric Microbial Biosensor for Direct Determination of p-Nitrophenyl-Substituted Organophosphate Nerve Agents," Environmental Science and Technology, Vol. 39, 2005, pp. 8853-8857. doi:10.1021/es050720b

[67] V. A. Pedrosa, S. Paliwal, S. Balasubramanian, D. Nepal, V. Davis, J. Wild, E. Ramanculov and A. Simonian, "Enhanced Stability of Enzyme Organophosphate Hydrolase Interfaced on the Carbon Nanotubes," Colloids and Surfaces B Biointerfaces, Vol. 77, No. 1, 2010, pp. 69-74. doi:10.1016/j.colsurfb.2010.01.009

[68] J. H. Lee, J. Y. Park, K. Min, H. J. Cha, S. S. Choi and Y. J. Yoo, "A Novel Organophosphorus Hydrolase-Based Biosensor Using Mesoporous Carbons and Carbon Black for The Detection Of Organophosphate Nerve Agents," Biosensors and Bioelectronics, Vol. 25, No. 7, 2010, pp. 1566-1570. doi:10.1016/j.bios.2009.10.013

[69] R. P. Deo, J. Wang, I. Block, A. Mulchandani, K. A. Joshi, M. Trojanowicz, F. Scholz, W. Chen and Y. H. Lin, "Determination of Organophosphate Pesticides at a Carbon Nanotube/Organophosphorus Hydrolase Electroche- mical Biosensor,” Analytica Chimica Acta, Vol. 530, No. 2, 2005, pp. 185-189. doi:10.1016/j.aca.2004.09.072

[70] T. Laothanachareon, V. Champreda, P. Sritongkham, M. Somasundrum and W. Surareungchai, "Cross-Linked Enzyme Crystals of Organophosphate Hydrolase for Electrochemical Detection of Organophoshorus Compounds," World Journal of Microbiology and Biotechnology, Vol. 24, No. 12, 2008, pp. 3049-3055. doi:10.1007/s11274-008-9851-yOpen

[71] V. Sacks, I. Eshkenazi, T. Neufeld, C. Dosoretz and J. Rishpon, "Immobilized Parathion Hydrolase: An Amperometric Sensor for Parathion,” Analytical Chemistry, Vol. 72, No. 9, 2000, pp. 2055-2058. doi:10.1021/ac9911488

[72] D. Du, W. Chen, W. Zhang, D. Liu, H. Li and Y. Lin, "Covalent Coupling of Organophosphorus Hydrolase Loaded Quantum Dots to Carbon Nanotube. Au Nanocomposite for Enhanced Detection of Methyl Parathion," Biosensors and Bioelectronics, Vol. 25, No. 6, 2010, pp. 1370-1375. doi:10.1016/j.bios.2009.10.032

[73] S. H. Chough, A. Mulchandani, P. mulchandani, W. Chen, J. Wang and K. R. Rogers, "Organophosphorus Hydrolase-Based Amperometric Sensor: Modulation of Sensitivity and Substrate Selectivity," Electroanalysis, Vol. 14, No. 4, pp. 273-276. doi:10.1002/1521-4109(200202)14:4<273::AID-ELAN27 3>3.0.CO;2-5

[74] A. Merkoci, "Biosensing Using Nanomaterials," John Wiley \& Sons Ltd., Hoboken, 2009. doi:10.1002/9780470447734

[75] A. Periasamy, Y. Umasankar and S. M. Chen, "Nanomaterials-Acetylcholinesterase Enzyme Matrices for Organophosphorus Pesticides Electrochemical Biosensors: A Review," Sensors, Vol. 9, 2009, pp. 4034-4055. doi:10.3390/s90604034

[76] M. Campàs, B. Prieto-Simón and J. L. Marty, “A Review of the Use of Genetically Engineered Enzymes in Electrochemical Biosensors," Seminars in Cell \& Developmental Biology, Vol. 20, No. 1, 2009, pp. 3-9. doi:10.1016/j.semcdb.2009.01.009 